\title{
Henryk PIETRAS SJ, Początki teologii Kościoła, Kraków 2000, Wydawnictwo WAM, ss. 402.
}

Nareszcie mamy pierwszy czysto polski podręcznik do teologii patrystycznej, podręcznik napisany łatwym i zrozumiałym językiem, w swej strukturze czytelny i przejrzysty, ubogacony po raz pierwszy obfitą, wyłącznie polską, bibliografią patrystyczną, do której student nie znający jeszcze języków obcych łatwo może dotrzeć i poszerzyć swoje wiadomości na temat nauki Ojców Kościoła. Zastąpi on zapewne, albo będzie konkurował, z powszechnie dotąd używanym (ale trudniejszym i zbyt zwartym) klasycznym podręcznikiem J.N.D. Kelly'ego - Początki doktryny chrześcijańskiej (tłum. J. Mrukówna, Warszawa 1988) z umieszczoną na końcu do poszczególnych zagadnień bibliografią obcojęzyczną, z dołączoną do niej przez Cz. Mazura wybraną bibliografią polską.

Autor, jezuita Henryk Pietras, długoletni i doświadczony profesor patrologii w Krakowie i Rzymie, zasłużony wydawca wielu publikacji patrystycznych (m.in. twórca i redaktor serii „Źródła Myśli Teologicznej”), skupia w swej książce „całą uwagę na rozwoju świadomości Kościoła na swój temat i na teologii”, oraz pragnie ukazać, ,jak ona się rodziła w środowisku judeochrześcijańskim, jak uczyła się po grecku i po łacinie, jak asymilowała wartości właściwe dla greckiej i rzymskiej kultury, jak znajdowała dla siebie miejsce między systemami myślenia proponowanymi przez różne szkoły filozoficzne [...]. Wiara była jej pierwszym założeniem, a równocześnie kryterium prawdziwości twierdzeń i hipotez" (s. 5-6). Tę zaś ogólnie nakreśloną tematykę rozpracowuje szczegółowo $\mathrm{w}$ trzech zasadniczych wzrastających objętościowo rozdziałach: I. Nowe wino w starych bukłakach (s. 13-39), przedstawia pierwsze zalążki teologii u Ojców Apostolskich i apologetów, oraz omawia problem prześladowań, męczenników i akt męczeńskich. W rozdziale II: Bycie w Kościele (s. 41-130) ukazuje początki eklezjologii omawiając przy niej miejsca święte (bazyliki, baptysteria, cmentarze), a także ówczesną sakramentologię - chrzest, eucharystię i pokutę, wspólnotę wierzących (małżeństwo i jego teologię), różne formy monastycyzmu, hierarchię kościelną (biskupów, prezbiterów i diakonów), a także chrześcijańskie szkoły i agnostycyzm. W rozdziale III: Wykład wiary (s. 131-333) przedstawia najpierw naukę o Piśmie św. i różne formy jego egzegezy, naukę o Bogu Ojcu, o Synu Bożym i Jego Wcieleniu, o Duchu Świętym i przejawach Jego działalności, o dziele stworzenia aniołów i ludzi, o pierwszym i drugim grzechu człowieka oraz jego skutkach, o eschatologii i Symbolu Apostolskim. Do tej części dołączony jest krótki rozdział IV: Kościót o sobie samym (s. 335-342) poświęcony ogólnej refleksji nad dziejami i wartością tradycji. Tego rodzaju osnowa poprzedzona jest na wstępie Wskazówkami bibliograficznymi (s. 8-11), w których przedstawiony jest podstawowy warsztat pracy patrologa (wykaz skrótów, najważniejsze tłumaczeniowe pol- 
skie serie wydawnicze, a także podstawowe polskojęzyczne podręczniki do patrologii i teologii patrystycznej) oraz zakończona rozległym epilogiem: Słowniki $i$ indeksy (s. 343-397) zawierającym alfabetyczny słownik osób (autorów wczesnochrześcijańskich) z krótkimi biogramami i wykazem ich podstawowych dzieł (s. 343-369), alfabetyczne zestawienie ważniejszych (48) pojęć (np. apoftegmaty, apokryfy, millenaryzm, doketyzm, Edykt Mediolański, kanon biblijny, stylici, itd.), indeksem biblijnym (s. 387-389), indeksem imion (s. 390-393) $\mathrm{i}$ indeksem tematów (s. 394-397) inaczej rzeczowym.

Łatwo zauważyć, że struktura prezentowanej książki odbiega nieco od struktury klasycznych tego rodzaju podręczników do teologii patrystycznej (np. Kelly'ego), w których przedstawia się chronologiczny rozwój nauki o Piśmie św. i Tradycji, naukę trynitarną, chrystologię, pneumatologię, eklezjologię, naukę o poszczególnych sakramentach, eschatologię, mariologię i hagiografię. Choć ta tematyka tradycyjna mieści się w ogromnej większości w nowym podręczniku, to jednak nie cała. Czy jednak w książce mającej być podręcznikiem teologii patrystycznej dla studentów teologii, można pominąć np. wczesnochrześcijańską mariologię i hagiografię, nie wspomnieć o sakramencie bierzmowania czy sakramencie chorych, a w eschatologii omówić jedynie tradycję hebrajską, millenaryzm, apokatastasis i końcowe zmartwychwstanie, nie wspominając o sądzie, niebie i piekle? Można więc dyskutować, na ile omawiana książka jest podręcznikiem do teologii patrystycznej, a na ile, przynajmniej w tradycyjnym znaczeniu, nim nie jest.

Nie decydując się na kategoryczną odpowiedź, czy jest to pełny podręcznik czy nie, trzeba podkreślić, że jest to książka wyjątkowo cenna i stanowi pewne novum na naszym patrystycznym polu wydawniczym. Można by tu wyliczać wiele jej pozytywnych walorów, jak choćby łatwy i żywy zachęcający do lektury język, ale do jednych z zasadniczych jej przymiotów należy niewątpliwie dowartościowanie polskiej bibliografii, dobranie jej i włączenie do poszczególnych zagadnień, a okazuje się, że nie jest ona już taka mała i nie musimy mieć wcale kompleksów wobec patrologów zachodnich, tylko chciejmy ją poznać i wykorzystywać. Szkoda tylko, że jej zapisy bibliograficzne nie zawsze są dopracowane (np. brak stron s. 179 T. Grodecki i s. 314 J. Wojtczk = Wojtczak) i nie zawsze wprowadzone zapowiedziane na początku w wykazie (s. 8) skróty czasopism (np. s. 26, 66, 263, 267, 287), a nawet wprowadzone nowe (np. s. 324 , zamiast przyjętego SACh jest StantChr). Na uwagę zasługują również krótkie dobrze dobrane fragmenty pism Ojców Kościoła, ilustrujące omawiane zagadnienia. Dobre i pomocne dla czytelników są także umieszczone na końcu „indeksy osób” z krótką charakterystyką bio- i bibliograficzną oraz zestawienia objaśnionych ważniejszych stosowanych w książce pojęć, które aczkolwiek nie są jednorodne (np. apoftegmaty, data Wielkanocy, Edykt Mediolański, Kanon biblijny, „kradzież Greków” itd.), bardzo ułatwiają lekturę książki. Lekturę tę ułatwia także sam układ graficzny książki - umieszczenie na zewnętrznej części 
strony nazwisk (z datą śmierci) omawianego autora wczesnochrześcijańskiego, a w ramkach na zewnętrznej części strony nazw omawianych zagadnień. Należy się spodziewać, iż nakład tej dobrej polskiej patrystycznej publikacji szybko się wyczerpie, a w drugim wydaniu można będzie uzupełnić zauważone wyżej usterki.

Ks. Stanisław Longosz - Lublin 